\title{
Monitoring of Bacterial Contaminations in Clinical Transfusion Medicine*
}

\author{
Erwin Strobel Peter Gleich \\ Institut für Medizinische Mikrobiologie, Immunologie und Krankenhaushygiene, Klinikum Schwabing, \\ Städtisches Klinikum München GmbH, München, Germany
}

\section{Key Words}

Nosocomial infection control · Clinical transfusion medicine . Infection control program - Surveillance of infection control

\section{Summary}

Background: For storage, transport and administration of blood products, German transfusion guidelines stipulate an infection control program in each hospital. Monitoring of bacterial contaminations shall help to improve the realization of this program. Materials and Methods: Two refrigerators for storage of blood products on wards, three thawing devices for fresh frozen plasma (FFP), two cell savers for intraoperative autologous blood collection, and several blood warmers for massive transfusions were screened semiquantitatively by impression plates. Also two water baths for thawing of blood stem cell transplants, which had to be filled with sterile fluids only whilst using, were swabbed. The examinations were repeated after 4, 12, 16 and 31 months. Results: The refrigerators, cell savers and blood warmers showed a low to modest number of environmental bacteria $\left(0-50 \mathrm{CFU} / 25 \mathrm{~cm}^{2}\right)$. Only in the water from the reservoir of one of the blood warmers we found repeatedly high numbers of Gram-negative non-fermenting rods (>100 CFU/ml). The thawing devices for FFP were sometimes contaminated with a high number of environmental bacteria and moulds $\left(>50 \mathrm{CFU} / 25 \mathrm{~cm}^{2}\right)$. At one occasion, one of the water baths showed growth of a high number of bacteria ( $>50 \mathrm{CFU} / 25 \mathrm{~cm}^{2}$ ). Meanwhile, the blood warmer with water reservoir and the water baths have been replaced by more suitable devices. Conclusion: Monitoring of bacterial contaminations should be done routinely also in clinical transfusion medicine. Such examinations allow for recognizing problems, and recommending actions to eliminate weak points.

*Parts of this paper had been presented as a poster contribution at the 37. Jahreskongress der Deutschen Gesellschaft für Transfusionsmedizin und Immunhämatologie in Mannheim (21. bis 24. September 2004)

\section{Schlüsselwörter}

Krankenhaushygiene - Klinische Transfusionsmedizin . Hygieneplan · Hygienische Überwachungsuntersuchungen

\section{Zusammenfassung}

Hintergrund: Für Lagerung, Transport und Verabreichung von Blutprodukten fordern die deutschen Transfusionsrichtlinien in jedem Krankenhaus einen Hygieneplan. Krankenhaushygienische Untersuchungen sollen helfen, dessen Umsetzung zu verbessern. Material und Methoden: Mittels semiquantitativ bewerteter Abklatschkulturen wurden zwei Blutkonservenkühlschränke auf Station, drei Auftaugeräte für gefrorene Frischplasmen (GFP), zwei Cellsaver für die intraoperative Autotransfusion und mehrere Blutwärmegeräte für Massivtransfusionen untersucht. Außerdem wurden zwei Wasserbäder zum Auftauen von Stammzellpräparaten kontrolliert, die nur bei Bedarf mit steriler Flüssigkeit befüllt werden sollten. Die Untersuchungen wurden nach 4, 12, 16 und 31 Monaten wiederholt. Ergebnisse: Zu den Untersuchungszeitpunkten fand sich bei den Kühlschränken, Cellsavern und Blutwärmegeräten eine geringe oder mäßige Zahl von Umweltkeimen $\left(0-50 \mathrm{KBE} / 25 \mathrm{~cm}^{2}\right)$. Nur im Wasser aus dem Tank eines der Blutwärmegeräte waren wiederholt hohe Zahlen von nichtfermentierenden gramnegativen Stäbchenbakterien (>100 KBE $/ \mathrm{ml}$ ) nachzuweisen. Die Auftaugeräte für GFP waren zu einzelnen Zeitpunkten mit einer hohen Zahl (>50 KBE $/ 25 \mathrm{~cm}^{2}$ ) von Umweltbakterien und Pilzen kontaminiert. Bei einem Wasserbad wurde an einem Termin reichliches Bakterienwachstum (>50 KBE $/ 25 \mathrm{~cm}^{2}$ ) festgestellt. Inzwischen wurden das Blutwärmegerät mit Wasserreservoir und die Wasserbäder durch geeignete Geräte ersetzt. Schlussfolgerung: Krankenhaushygienische Untersuchungen sollten routinemäßig auch in der klinischen Transfusionsmedizin vorgenommen werden. Durch solche Untersuchungen können Probleme erkannt und Maßnahmen zur Elimination von Schwachstellen empfohlen werden.

\begin{tabular}{ll}
\hline KARGER & @ 2007 S. Karger GmbH, Freiburg \\
Fax +4976145207 14 & Accessible online at: \\
$\begin{array}{l}\text { E-mail Information@Karger.de } \\
\text { www.karger.com }\end{array}$ & www.karger.com/tmh
\end{tabular}

PD Dr.med. Dr.phil. Erwin Strobel

Institut für Medizinische Mikrobiologie, Immunologie und Krankenhaushygien Klinikum Schwabing, Städtisches Klinikum München GmbH Kölner Platz 1, 80804 München, Germany Tel. +49 89 3068-3360, Fax -3835

E-mail Mikrobiologie@kms.mhn.de 


\section{Introduction}

Blood donation services take a lot of measures to reduce the risk of transfusion-associated infections, for example:

- careful selection of blood donors by obtaining their medical history, physical examination and giving the opportunity of confidential unit exclusion [1],

- prevention of bacterial contamination during blood collection and component preparation, e.g. by skin disinfection before phlebotomy, predonation sampling and use of sterile closed systems of blood bags [2,3],

- laboratory testing of the donated blood for Treponema pallidum, HBV, HCV and HIV, in special cases also for other pathogens like CMV, in the case of FFP repeated testing of the donor before issue of the quarantine plasma $[4,5]$,

- leukocyte depletion for reducing pathogens (e.g. Yersinia enterocolitica or CMV) [6],

- inactivation of pathogens (e.g. solvent/detergent treatment of pooled plasma) [7],

- random sterility controls of the blood products [8], and

- proper blood component storage and shipping, continuously maintaining the correct temperature [9].

Also in hospitals and other patient care units several measures are taken to reduce the risk of infection for the recipients, for example

- different methods of autologous hemotherapy in suitable patients (e.g. preoperative autologous blood donation or intraoperative blood collection by using a cell saver) [10],

- proper blood component storage and transporting, continuously maintaining the correct temperature [11],

- aseptical techniques for administration of blood products (e.g. venous access) [12, 13],

- examination of all suspected cases of adverse transfusion reactions, including sterility testing of the involved blood products [14], and

- starting look-back in cases of suspected transfusion-associated infections $[15,16]$.

German transfusion guidelines prescribe an infection control program for storage, transportation and administration of blood products in each hospital [17]. To improve the realization of this program, we have established in our hospital the monitoring of bacterial contaminations also in clinical transfusion medicine.

\section{Materials and Methods}

The following equipment used for blood transfusion in our hospital was examined:

- two refrigerators (Philipp Kirsch GmbH, Offenburg, Germany) for red blood cell concentrates (on wards),

- three thawing devices for fresh frozen plasma (Barkey $\mathrm{GmbH}$, Leopoldshöhe, Germany),

- two water baths used for thawing stem cell concentrates and fresh frozen plasma, that were filled with sterile fluid before use and evacuated and disinfected after use,
- $\quad$ several blood warmers for massive transfusion (Level 1 Technologies, Inc., Rockland, MA, USA; distributor: MC Medizintechnik GmbH, Alzenau, Germany), one of them with a water reservoir that had to be filled before use,

- two cell savers for intraoperative autologous blood collection (C.A.T.S. ${ }^{\circledR}$, Fresenius, Oberursel, Germany).

After the 4th examination both water baths were replaced by thawing devices not needing water. From this time these new devices were examined. As the blood warmer with water reservoir was replaced by a new blood warmer (without such a reservoir) at the time of the 5th examination, it was also no longer examined.

The equipment was placed on the following wards:

- critical care unit for surgical patients,

- critical care unit for children.

- critical care unit for non-surgical patients,

- central operating rooms,

- emergency room

- stem cell transplantation unit for adults,

- stem cell transplantation unit for children.

The 2 nd examination was carried out 4 months, the $3 \mathrm{rd} 12$ months, the 4 th 16 months and the 5 th about 31 months after the 1 st examination.

Bacteriological examination was done by direct contact cultures that were taken from several places of the refrigerators, the thawing devices and the cell savers, especially also from their inner rooms (e.g. the centrifuge chamber of the cell saver and the shelves of the thawing devices). For the inner room of the water baths impression plates as well as swabs were used. Direct contact cultures were made also from the surface of the blood warmers. From the water reservoir of one blood warmer a water sample was taken.

For the direct contact cultures impression plates (Rodac plates) with sheep blood agar were used, that were incubated at $36 \pm 1{ }^{\circ} \mathrm{C}$ for 24 and $48 \mathrm{~h}$ [18]. The examinations were done as a screening, and therefore no special culture conditions for moulds were chosen. The contact area of the impression plates was $25 \mathrm{~cm}^{2}$. On the basis of this area the CFU numbers were used for defining the semiquantitative results of the bacteriological examination.

The swabs from the water baths were plated on solid media (sheep blood agar) and cultured in CASO-Bouillon. The water sample from the water reservoir of one blood warmer was examined by membrane filtration technique on sheep blood agar [19].

\section{Results}

The examinations of the two refrigerators on wards showed growth of $0-50 \mathrm{CFU} / 25 \mathrm{~cm}^{2}$ environmental bacteria such as Bacillus sp., coagulase-negative staphylococci, Micrococcus sp. and in one device only at one occasion and on one position also 1-5 CFU/25 $\mathrm{cm}^{2}$ moulds. Similar results were found for both cell savers: $0-50 \mathrm{CFU} / 25 \mathrm{~cm}^{2}$ environmental bacteria (Bacillus sp., coagulase-negative staphylococci, Micrococcus sp. and in one device only at one occasion and on one place also viridans streptococci). No significant trends of contaminations were seen over the time.

On the blood warmers for massive transfusion we also found 0-50 CFU/25 $\mathrm{cm}^{2}$ environmental bacteria (Bacillus sp., Micrococcus sp., coagulase-negative staphylococci). Only in the water from the reservoir of another blood warmer, repeatedly high numbers of Gram-negative non-fermenting rods $(>100 \mathrm{CFU} / \mathrm{ml})$ could be detected. 


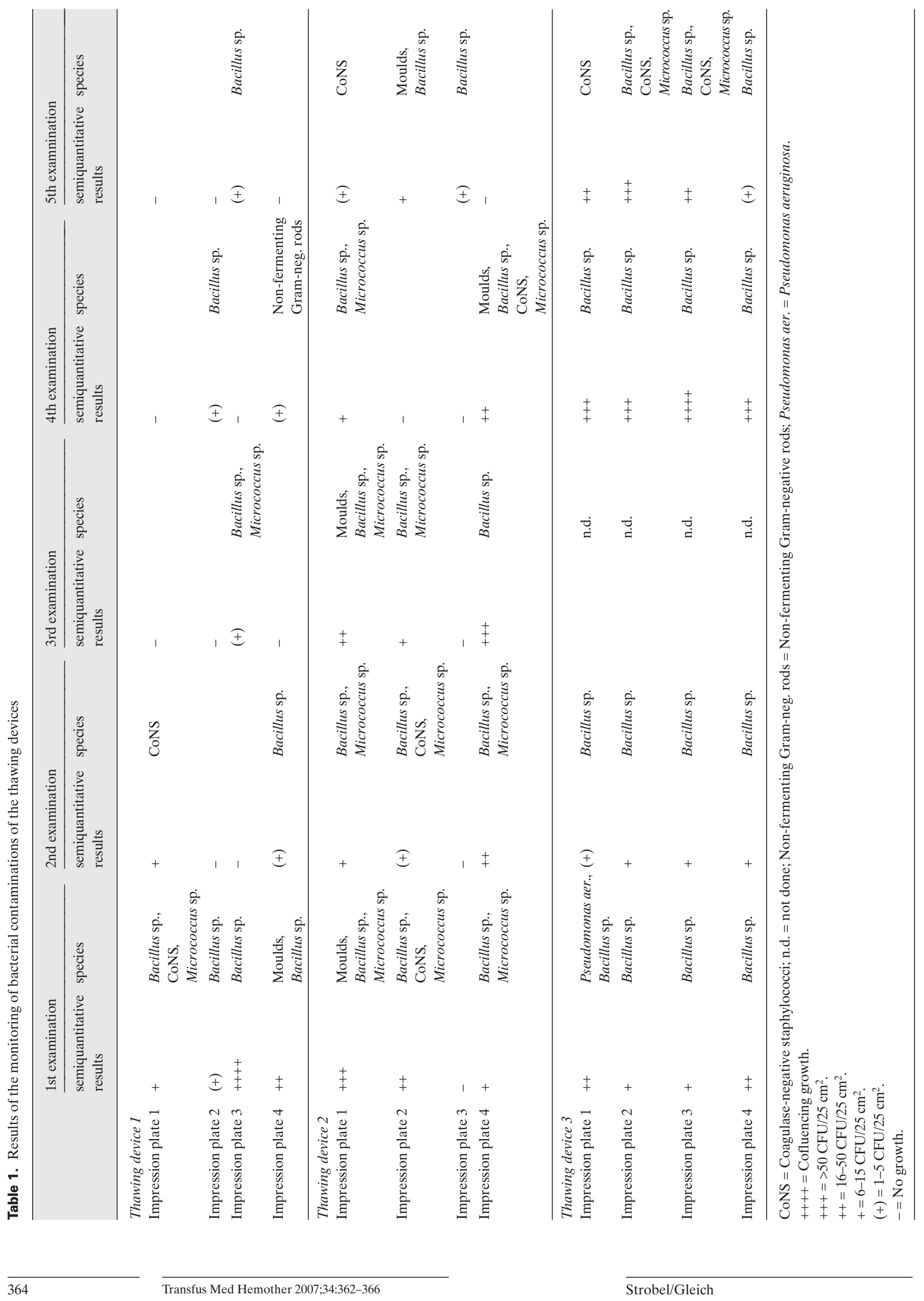


Water baths for thawing stem cell concentrates and fresh frozen plasma were used on the precondition that they were filled with sterile fluid only before use and evacuated and disinfected immediately after use. In 3 of 4 examinations one water bath was empty, and no bacterial contamination was found. But at one occasion it was filled, and we found Bacillus sp. and non-fermenting Gram-negative rods $(1 \mathrm{CFU} / \mathrm{ml})$ in a water sample. This demonstrated that such devices are not appropriate for thawing procedures. Therefore, the water baths were replaced in the following time by devices not needing water.

On the thawing devices, environmental bacteria (Bacillus sp., coagulase-negative staphylococci, Micrococcus sp.) sometimes were found in a great number $\left(>50 \mathrm{CFU} / 25 \mathrm{~cm}^{2}\right)$. Also moulds could be detected on 2 of the 3 thawing devices at some places at several times. Non-fermenting Gram-negative rods were found only at two occasions. There was no significant trend of contamination over the time, demonstrating that prevention of bacterial contaminations is a continuous process requiring repeated efforts (table 1 ).

\section{Discussion}

In general microbiological surveillance examinations in hospitals and other patient care units are used for quality assurance, because they can help

- to recognize infection risks for patients and staff,

- to monitor measures of infection control and to document the efficacy of decontamination and disinfection, and

- to motivate staff by information and training [20].
In our microbiological surveillance examinations several pieces of equipment that are used for administration of blood products were tested for bacterial contaminations. The results were communicated to the transfusion representatives and the heads of the clinical departments together with the recommendation to take care that the required measures of regular cleaning and disinfection are done. In this context the results of our examinations could also be used for the instruction of the other staff. In intervals of some months up to 1 year we repeated our examinations several times as prevention of nosocomial infections is a continuous process.

Some important results of our examinations were:

- Thawing devices for fresh frozen plasma also need to be cleaned regularly as the inner room of their shelves may be contaminated by environmental bacteria and moulds.

- In the water reservoir of a blood warmer for massive transfusion we repeatedly found a number of bacteria greater than allowed for drinking water. As this problem could not be resolved by measures of handling this device, we proposed to replace this device by another without such a reservoir.

Based on the results of our study we recommend to regularly perform (e.g. once a year) some selected microbiological examinations also in clinical transfusion medicine to improve the realization of the infection control program in the hospital. By this surveillance latent problems can be uncovered, and measures to eliminate risks can be specifically proposed. Still more important is the educational impact of such examinations as they can demonstrate the importance of continuously obeying the rules for prevention of nosocomial infections.

\section{References}

1 Wissenschaftlicher Beirat der Bundesärztekammer und Paul-Ehrlich-Institut: Richtlinien zur Gewinnung von Blut und Blutbestandteilen und zur Anwendung von Blutprodukten (Hämotherapie) gemäß $\S \S 12$ und 18 des Transfusionsgesetzes (Novelle 2005). Bundesanzeiger Nr. 209a vom 05.11.2005, Ziff. 2.1 and 2.2.

2 Wissenschaftlicher Beirat der Bundesärztekammer und Paul-Ehrlich-Institut: Richtlinien zur Gewinnung von Blut und Blutbestandteilen und zur Anwendung von Blutprodukten (Hämotherapie) gemäß $\S \S 12$ und 18 des Transfusionsgesetzes (Novelle 2005).Bundesanzeiger Nr. 209a vom 05.11.2005, Ziff. 2.3.1 and 3.

3 Arbeitskreis Blut: Votum 27: Einführung des 'predonation sampling'. Bundesgesundheitsbl Gesundheitsforsch Gesundheitsschutz 2002;45:756.

4 Wissenschaftlicher Beirat der Bundesärztekammer und Paul-Ehrlich-Institut: Richtlinien zur Gewinnung von Blut und Blutbestandteilen und zur Anwendung von Blutprodukten (Hämotherapie) gemäß $\S \S 12$ und 18 des Transfusionsgesetzes (Novelle 2005). Bundesanzeiger Nr. 209a vom 05.11.2005, Ziff. 2.4.1, 3.1.4.1 and 4.5.6.
5 Paul-Ehrlich-Institut: Abwehr von Arzneimittelrisiken; Testung auf Antikörper gegen Hepatitis-BCore-Antigen (anti-HBc) im Blutspendewesen. Bundesanzeiger Nr. 109 vom 13.06.2006.

6 Paul-Ehrlich-Institut: Bekanntmachung über die Ergebnisse des Stufenplanverfahrens zur Einführung der Leukozytendepletion von zellulären Blutprodukten zur Transfusion vom 18.08.2000; Bundesanzeiger Nr. 174 vom 14.09.2000.

7 Biesert L, Gärtner T, Lemon S, Horowitz B, Suhartono H, Wang L, Brede HD: Octaplas: Eine virusinaktivierte Alternative zu gefrorenem Frischplasma. Infusionsther Transfusionsmed 1995;22 (suppl 1):2-4.

8 Arbeitskreis Blut: Votum 16: Mindestanforderungen zur Sterilitätstestung von Blutkomponenten. Bundesgesundheitsbl 1997;40,307-309.

9 Wissenschaftlicher Beirat der Bundesärztekammer und Paul-Ehrlich-Institut: Richtlinien zur Gewinnung von Blut und Blutbestandteilen und zur Anwendung von Blutprodukten (Hämotherapie) gemäß $\S \S 12$ und 18 des Transfusionsgesetzes (Novelle 2005). Bundesanzeiger Nr. 209a vom 05.11.2005, Ziff. 3.2
10 Pruß A, Biscoping J, Salama A, Kiesewetter H: Autologe Hämotherapie; in Vorstand und Wissenschaftlicher Beirat der Bundesärztekammer (ed): Leitlinien zur Therapie mit Blutkomponenten und Plasmaderivaten. Köln, Deutscher Ärzte-Verlag, 2003, pp 243-255.

11 Wissenschaftlicher Beirat der Bundesärztekammer und Paul-Ehrlich-Institut: Richtlinien zur Gewinnung von Blut und Blutbestandteilen und zur Anwendung von Blutprodukten (Hämotherapie) gemäß $\S \S 12$ und 18 des Transfusionsgesetzes (Novelle 2005). Bundesanzeiger Nr. 209a vom 05.11.2005, Ziff. 4.1.

12 Wissenschaftlicher Beirat der Bundesärztekammer und Paul-Ehrlich-Institut: Richtlinien zur Gewinnung von Blut und Blutbestandteilen und zur Anwendung von Blutprodukten (Hämotherapie) gemäß $\S \S 12$ und 18 des Transfusionsgesetzes (Novelle 2005). Bundesanzeiger Nr. 209a vom 05.11.2005, Ziff. 4.3.3.

13 Kommission für Krankenhaushygiene und Infektionsprävention beim Robert Koch-Institut: Prävention Gefäßkathether-assoziierter Infektionen. Bundesgesundheitsbl Gesundheitsforsch Gesundheitsschutz 2002;45:907-924. 
14 Wissenschaftlicher Beirat der Bundesärztekammer und Paul-Ehrlich-Institut: Richtlinien zur Gewinnung von Blut und Blutbestandteilen und zur Anwendung von Blutprodukten (Hämotherapie) gemäß $\S \S 12$ und 18 des Transfusionsgesetzes (Novelle 2005). Bundesanzeiger Nr. 209a vom 05.11.2005, Ziff. 4.5.1.

15 Gesetz zur Regelung des Transfusionswesens vom 1.7.1998 (TFG); § 19 Abs. 2. BGBl I, 1752-1760.

16 Arbeitskreis Blut: Votum 24: Verfahren zur Rückverfolgung (Look back) (gemäß § 19 Transfusionsgesetz). Bundesgesundheitsbl Gesundheitsforsch Gesundheitsschutz 2001;44:305-310.

17 Wissenschaftlicher Beirat der Bundesärztekammer und Paul-Ehrlich-Institut: Richtlinien zur Gewinnung von Blut und Blutbestandteilen und zur Anwendung von Blutprodukten (Hämotherapie) gemäß $\S 12$ und 18 des Transfusionsgesetzes (Novelle 2005). Bundesanzeiger Nr. 209a vom 05.11.2005, Ziff. 4.

18 Trautmann M, Christiansen B, Häfner H, Lemmen S, Martiny H, Okpara-Hofmann J, Regnath T, Synowzik I, Thomsen J, Wendt C, Zeller E: Krankenhaushygienische Untersuchungen, Teil 1. Mikrobiologisch-infektiologische Qualitätsstandards (MiQ) 22. München, Urban and Fischer, 2005, pp 49-55.

19 Dietlein E, Exner M: Hygienisch-mikrobiologische Überwachung; in Kramer A, Heeg P, Botzenhart K: Krankenhaus- und Praxishygiene. München, Urban and Fischer, 2001, pp 748-749.

20 Hygienische Untersuchungen in Krankenhäusern und anderen medizinischen Einrichtungen. Anlage zu Ziffer 5.6 der Richtlinie für Krankenhaushygiene und Infektionsprävention. Bundesgesundheitsbl 1993:36:244-245. 